NATURE B Y D ESIG N 


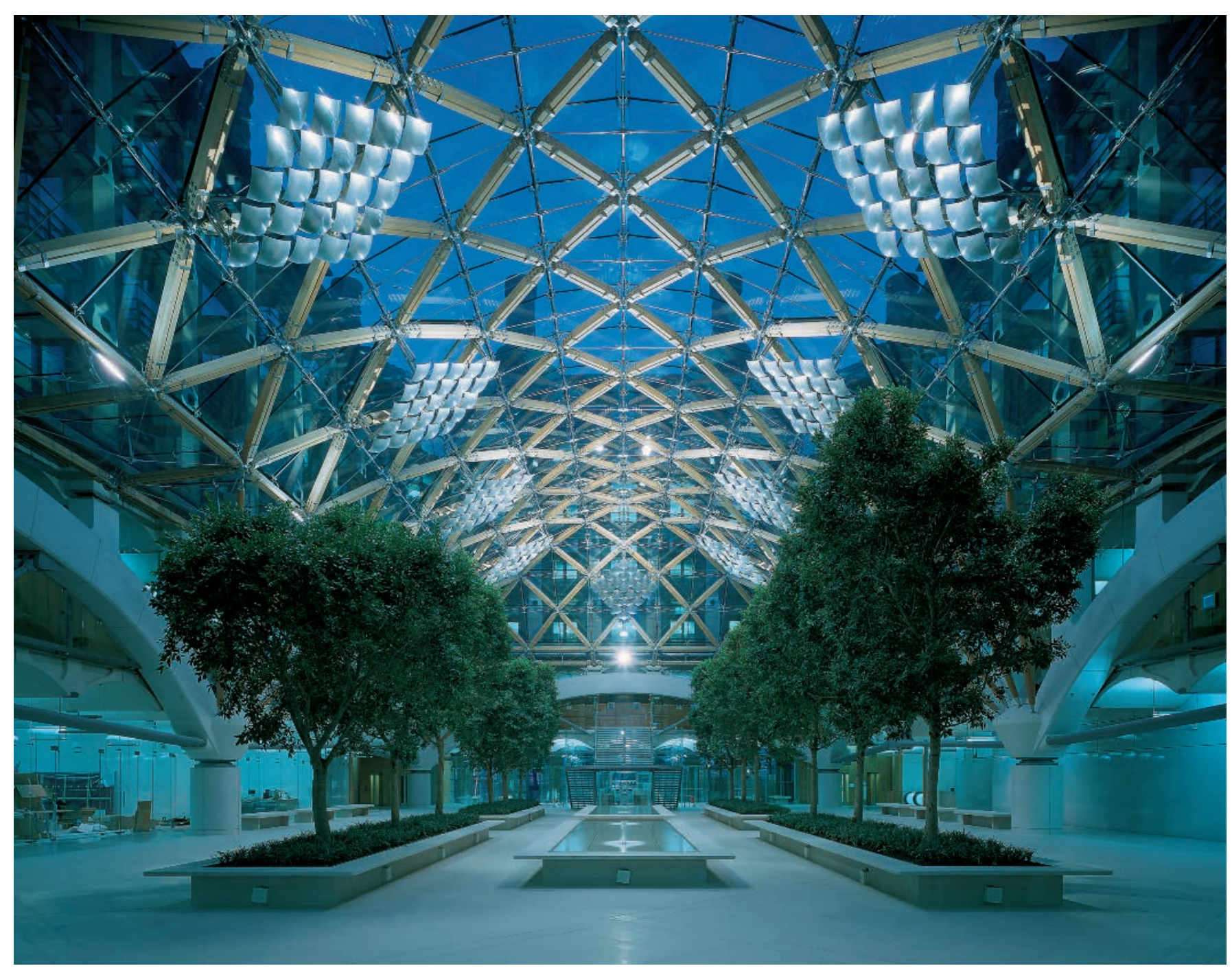




\title{
Nature by Design
}

THE PRACTICE OF BIOPHILIC DESIGN

\author{
STEPHEN R. KELLERT
}


We gratefully acknowledge funding from Interface, Inc., which supported the research and illustrations program.

Frontispiece: The Portcullis House courtyard, designed by Hopkins Architects Partnership LLP, connects parliamentary offices in London. It is a compelling and enthralling combination of both direct and indirect biophilic design features. The natural world is brought inside by the column of trees and the water pools. And the spiderweb-like framing of the roof and its

skylights makes the connection to nature even more dramatic.

Copyright $\odot 2018$ by Stephen R. Kellert.

All rights reserved.

This book may not be reproduced, in whole or in part, including illustrations, in any form (beyond that copying permitted by Sections 107 and 108 of the U.S. Copyright Law and except by reviewers for the public press), without written permission from the publishers.

Yale University Press books may be purchased in quantity for educational, business, or promotional use. For information, please e-mail

sales.press@yale.edu (U.S. office) or sales@yaleup.co.uk (U.K. office).

Designed by Mary Valencia.

Set in Adobe Garamond type by Tseng Information Systems, Inc. Printed in China.

Library of Congress Control Number: 2017943458 ISBN 978-0-300-21453-6 (hardcover : alk. paper)

A catalogue record for this book is available from the British Library.

This paper meets the requirements of ANSI/NISO Z39.48-1992 (Permanence of Paper)

10987654321 